блемы биологии, химии, экологи и экологического образования: Регион. сб. науч. тр. Ярославль: Изд-во Яросл. гос. ун-та, 2001. С. 133-136.

10. Борисова Е.А. Луговое - один из интересных природно-флористических комплексов в окрестностях г. Кинешма // Историко-культурный и природный потенциал Кинешемского края. Кинешма, 2006. С. 161-163.

11. По земле Ивановской: Историко-краеведческие очерки. Ярославль: Верх.-Волж. кн. изд-во, 1983. 319 с.

12. Попович А.А. История изучения городища в поселке Лух // Краеведческте записки. Вып. IX, Иваново: Иван. гос. ун-т, 2009. С. 25-28.

13. Ерофеева Е.Н. Археологические памятники Ивановской области. Ярославль: Верхне-волжск. кн. издво, 1965.

14. Борисова Е.А. Новые адвентивные виды растений в Ивановской и Владимирской областях // Бюл. МОИП, Отд. Биол. 2009. Т. 114, вып. 6. С. 61-62.

15. Красная книга Ивановской области. Т. 2: растения и грибы / Е.А. Борисова, М.А. Голубева, М.П. Шилов и др. Иваново: ПресСто, 2010. 192 с.

16. Борисова Е.А. Интересные флористические находки в поселке Лух и его окрестностях // Борисовский сборник. Вып. 3. / под ред. В.В. Возилова. Иваново: Изд. дом Референт, 2012. С. 190-193.

17. Серебряков И.Г. Экологическая морфология растений: жизненные формы покрытосеменных и хвойных. М.: Высш. школа, 1962. 378 с.
18. Борисова Е.А. Адвентивная флора Ивановской области. Иваново: Иван. гос. ун-т, 2007. 188 с.

19. Борисова Е.А., Голубева М.А. Сведения о новых заносных и дичающих видах в Ивановской, Костромской областях // Флористические исследования в Центральной России на рубеже веков: Материалы науч. совещ. М.: Бот. сад МГУ, 2001. С. 28-31.

20. Борисова Е.А.,, Сенюшкина И.В. Флористические находки в Ивановской области // Бюл. МОИП. Отд. биол. 2007. Т. 112, вып. 6. С. 41-42.

21. Борисова Е.А. Формирование адвентивного компонента флоры Верхневолжского региона // Биоразнообразие: проблемы изучения и сохранения: Матер. междунар. науч. конф., посв. 95-летию каф. ботаники Тверского гос. ун-та. Тверь: ТвГУ, 2012. С. 339-342.

22. Борисова Е.А. Инвазионные виды во флоре Верхневолжья // Актуальные вопросы изучения флоры Верхневолжья: Мат. регион. науч. конф. (Иваново, 12 13 окт. 2007 г.). Иваново: Иван. гос. ун-т, 2007. С. 14-20.

23. Борисова Е.А Особенности распространения инвазионных видов растений по территории Верхневолжского региона // Российский журн. биологических инвазий. 2010, № 4. С. 2-9.

24. Юрцев Б.А. Флора Сунтар-Хаята. Л.: Наука, 1968. $236 \mathrm{c}$.

25. Юрцев Б.А. Флора как природная система // Бюл. МОИП. Отд. биол. 1982. Т. 87, вып. 4. С. 3-32.

\title{
FLORA OF THE SETTLEMENT LUKH OF IVANOVO REGION
}

(C) 2016

E.A. Borisova, doctor of biological sciences, head of the Chair of General Biology and Physiology Ivanovo State University, Ivanovo (Russia)

Abstract. In the article the floristic data of Lukh, one of the ancient Ivanovo region settlements, are given. The present Lukh settlement flora consists of 402 vascular plant species from 4 classes, 76 families and 255 genera. Compositae - 53 species (13,2\%), Rosaceae - 39 species (9,7\%), Poaceae - 27 species (6,9\%), Fabaceae - 23 species $(5,7 \%)$, Cruciferae -18 species $(4,2 \%)$ are leading families of the flora. The basis of biomorphological structure of the Luch flora is made up by the perennial grass plants (233 species; 57,9\%), arboreous plants include 60 species (14,9\%), among which 23 species are trees, 33 species are shrubs. Geographical analysis ascertained prevalence of native species. The native component of Lukh flora comprises 247 species $(61,6 \%)$, the alien component -153 species $(38,4 \%)$. The adventivity index is 0,38 which is typical for the small towns and large settlements of the Upper Volga region. 2 rare species (Gerntiana pneumonanthe, Populus nigra) included in the regional red data book, some native (Thelypteris palustris, Juniperus communis, Dactulorhiza fuchii, Platanthera bifolia, Convallaria majalis, Carex pilosa, Trollius earopaeus, Daphne mezerum) and alien (Atriplex patens, Symphytum x uplandicum, Hesperis matronalis, Veronica persica, Zizania latifolia) rare plant species are briefly characterized.

Keywords: flora of the vascular plant species, anthropogenic transformation of the flora, human activity index, rare plant species, Red data book, alien plant species, invasion plant species, structure of the flora, flora of rural settlements, floristic data of ancient settlement, Ivanovo region, Lukh settlement.

УДК 574.5 (285.3); $504(1-21)$

\section{РАКООБРАЗНЫЕ И КОЛОВРАТКИ ПРУДА ВОЗЛЕ ТОРГОВОГО ЦЕНТРА «ПИРАМИДА» (Г. САМАРА) В 2013 Г.}

(C) 2016

Ю.Л. Герасимов, кандидат биологических наук, заведующий кафедрой зоологии, генетики и общей экологии Самарский государственный аэрокосмический университет имени академика С.П. Королева, Самара (Россия)

А.В. Шабанова, кандидат химических наук, доцент кафедры природоохранного и гидротехнического строительства Самарский государственный архитектурно-строительный университет, Самара (Россия)

Аннотащия. Изучены видовой состав и численность популяций ракообразных и коловраток городского пруда после проведения мелиоративных работ. В пруду выявлено 30 видов коловраток (до мелиорации отмечалось 52 вида). По численности сохранили доминирование семейства Brachionidae, Synchaetidae и Asplanchnidae. Ракооб- 
разных в 2013 г. выявлено 20 видов (до мелиорации - 33 вида). По численности доминировало семейство Сусlоpoidae (до мелиорации - семейство Daphniidae), значительно увеличилась численность семейств Bosminidae и Chydoridae. В целом численность зоопланктона в 2013 г. уменьшилась на 15\%. В 2010 г. наблюдались 2 подъёма численности: в июне и августе, а в 2013 г. только один - в июле. В популяциях увеличились доли самок с яйцами. По видам-индикаторам пруд относится к $\beta$-мезосапробной зоне, уменьшилось количество видов - индикаторов загрязнения. Рассчитаны величины индексов видового разнообразия Шеннона. Удаление зарослей водных растений вызвало уменьшение количества зарослевых видов и увеличение численности планктонных видов. Гидрохимический анализ показал превышение в воде пруда ПДК по БПК, АПАВ, меди, железа и цинка.

Ключевые слова: городской пруд, видовой состав, численность популяций, коловратки, ракообразные, химический состав воды, Самара, мелиорация, зоопланктон, гидрохимический анализ, Brachionidae, Synchaetidae, Asplanchnidae, Cyclopoidae.

Введение. Искусственные водоёмы, не связанные с производственной деятельностью, создаются на территории населённых пунктов, как правило, с эстетическими и рекреационными целями. Удачно спроектированный, качественно сооружённый и содержащийся в надлежащем порядке пруд гармонически вписывается в архитектурный ландшафт, оказывает благотворное действие, как на физический, так и на психологический климат окружающей территории [1,3]. Мы исследовали экосистему правого («Длинного») из двух прудов, расположенных в г. Самаре между улицами Солнечная и Ново-Садовая напротив ТЦ «Пирамида».

Район исследования. Пруд расположен на 3-й надпойменной террасе левого берега р. Волги (Саратовское водохранилище). Максимальная отметка бровки склона - 126,6 м, отметка уреза воды после весеннего паводка - 122,0 м. Многоэтажные дома расположены с северной и западной сторон пруда на расстоянии от 50 м. К юго-востоку в 150 м проходит улица НовоСадовая с интенсивным автомобильным движением, зимой на ней применяются антиобледенительные смеси. Территория между улицей и прудом занята второстепенной дорогой и сквером с детской площадкой.

Длина пруда около 60 м, ширина до 30 м, в восточной части 2 небольших залива. Площадь зеркала вес-

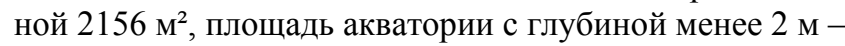
$701 \mathrm{M}^{2}$, средняя глубина около 1,5 м, максимальная глубина 3,64 м. Западный, южный и восточный берега довольно крутые, высота их до 3 м. Южный берег образован дамбой, за которой расположен второй (левый) пруд.

К концу ХХ века дамба сильно осела, и весной пруды соединялись перемычками глубиной до $30 \mathrm{~cm}$. Вдоль западного берега была полоса водо-воздушных растений шириной до 2 м к концу лета. Мелководья свободные от рогоза были заняты элодеей канадской. Вокруг пруда и на дамбе, растут высокие старые деревья и их подрост. Откосы покрыты травой. На мелководьях было много бытового мусора, в основном, упаковок. По поверхности плавали доски, куски дерева и мелкий мусор. В пруду водится ротан-головешка и местные жители ловят его на удочки, на берегу оборудованы сиденья для рыбаков. На дамбе в вечернее время собиралась молодёжь и распивала спиртные напитки.

В 2010 г. мы обнаружили в этом пруду 47 видов коловраток и 26 видов ракообразных.

В конце осени 2012 г. были проведены работы по очистке акватории пруда от макрофитов и укреплению берегов габионными конструкциями. Была увеличена высота дамбы, восстановлена её целостность, и теперь правый пруд полностью изолирован от левого на протяжении всего года.
Memodbl. В 2013 г. мы провели новое обследование пруда, чтобы выяснить, как повлияли мелиоративные работы на сообщество беспозвоночных. Пробы отбирали дважды в месяц с мая по октябрь в тех же точках, что и в 2010 г. по стандартным методикам планктонной сетью (газ № 64) и 2-л батометром $[2,11]$. Пробы обрабатывали стандартными методами $[4,5,6,9,10]$. Температура воды в дни отбора проб показана в табл. 1. Прозрачность воды 0,8-1,1 м по диску Секки. Был проведён гидрохимический анализ воды. Отбор проб для анализа осуществлялся 26.07.2013 и 5.10.2013 в соответствии с требованиями ГОСТ Р 51592-2000 «Вода. Общие требования к отбору проб». Вода была проанализирована по 27 показателям в гидрохимической лаборатории Самарского государственного архитектурно-строительного университета (аттестат аккредитации № POCC RU.0001.516292 от 07.04.2013). Определение содержания растворённого кислорода проводилось на месте с использованием тест-комплекта.

Таблица 1 - Изменения температуры воды в пруде у ТЦ «Пирамида» в 2013 г.

\begin{tabular}{|l|c|c|c|c|c|c|c|c|c|}
\hline Месяцы & V & VI & VI & VII & VII & VIII & VIII & XI & X \\
\hline Даты & 20 & 11 & 25 & 8 & 19 & 7 & 24 & 17 & 8 \\
\hline Температура & 18 & 18,6 & 22 & 25 & 22 & 20 & 21 & 15 & 4 \\
\hline
\end{tabular}

Были составлены формулы Курлова, характеризующие воду как гидрокарбонатную кальциево-магниевую пресную, достаточно постоянную по составу.

$$
\begin{aligned}
& M 0,49 \frac{\mathrm{HCO}_{3} 71\left[\mathrm{Cl}_{\left.20 \mathrm{SO}_{4} 5\right]}\right.}{M g 54 \mathrm{Ca} 46} p H 8,14 \text { - проба 26.07.2013 } \\
& M 0,48 \frac{\mathrm{HCO}_{3} 75[\mathrm{Cl} 2 \mathrm{~L}]}{\mathrm{Mg} 54 \mathrm{Ca} 46} \mathrm{pH}, 33 \text { - проба } 05.10 .2013
\end{aligned}
$$

Содержание азота нитратного составило до 0,08 ПДК (для рыбохозяйственных водоёмов), аммонийного - до 0,3 ПДК, нитритного - до 1,2 ПДК (в октябре), фосфатов - до 0,01 ПДК. Превышено в 2,9 раза нормативное значение БПК 0,6-0,7 ПДК. Содержание растворённого кислорода было не менее 4 мг/л. Согласно ГОСТ 17.1.1.04.77 «Показатели состояния и правила таксации рыбохозяйственных водоёмов» по трофо-сапробным показателям вода пруда может оцениваться как чистая. Летом незначительно превышалась ПДК нефтепродуктов. Содержание АПАВ от 4,3 до 6 ПДК. Содержание меди от 8,4 ПДК летом до 38 ПДК осенью, железа - до 4 ПДК. Максимальная концентрация цинка составила 2 ПДК, марганца - 0,6 ПДК. Содержание свинца и кадмия было ниже границы определения. В 2010 г. [1] содержание меди было существенно ниже (2,5 ПДК), остальные показатели изменились незначительно.

Результаты. В 2013 г. выявлено 30 видов коловраток из 16 родов и 13 семейств (табл. 2). По сравнению с 
2010 г. не обнаружено 22 вида из 12 родов и 12 семейств. Не найдено ни одного представителя 5-ти семейств (Collothecidae, Conochilidae, Dicranophoridae, Mytilinidae и Proalidae) и 7-ми родов (Collotheca, Conochilus, Dicranophorus, Eosphora, Mytilina, Dissotrocha и Proales). Из 22-х видов коловраток, не обнаруженных в 2013 г. 4 - планктонные, остальные 18 зарослевые и придонные. Brachionus calyciflorus с конца июня был представлен морфой Brachionus calyciflorus spinosus Wierzejski 1948, представители типичной морфы попадались единично. Появились 3 вида: Brachionus urceus (Linnaeus 1758), Rotaria rotatoria Scopoli, 1777 и Trichocerca similis (Weirzejski, 1893), отсутствовавших в пробах в 2010 г.

Таблица 2 - Виды коловраток, обитающие в пруде у ТЦ «Пирамида» и частота (\%) их встречаемости в пробах

\begin{tabular}{|c|c|c|}
\hline \multirow[t]{2}{*}{ Название таксона } & \multicolumn{2}{|c|}{$\begin{array}{l}\text { Частота встре- } \\
\text { чаемости (\%) }\end{array}$} \\
\hline & 2010 & 2013 \\
\hline \multicolumn{3}{|l|}{ Ceм.Asplanchnidae } \\
\hline Asplanchna girodi Guerne, 1888 & 60 & 74 \\
\hline A. priodonta Gosse, 1850 & 47 & 0 \\
\hline $\begin{array}{l}\text { Asplanchnopsis mutticeps } \\
\text { (Schrank,1793) }\end{array}$ & 13 & 0 \\
\hline \multicolumn{3}{|l|}{$\begin{array}{r}\text { Cем.Brachionidae } \\
\end{array}$} \\
\hline Brachionus angularis Gosse, 1851 & 40 & 26 \\
\hline B. calyciflorus Pallas, 1776 & 27 & 44 \\
\hline B. diversicornis Daday, 1883 & 7 & 15 \\
\hline B. quadritentatus Hermann, 1783 & 0 & 11 \\
\hline Brachionus urceus (Linnaeus 1758) & 0 & 11 \\
\hline Keratella cochlearis (Gosse, 1851) & 60 & 89 \\
\hline K. quadrata (Muller, 1786) & 93 & 56 \\
\hline K. valga (Ehrenberg, 1834) & 13 & 4 \\
\hline Platias quadricornis Ehrenberg, 1832 & 87 & 26 \\
\hline \multicolumn{3}{|l|}{\begin{tabular}{|c|} 
Ceм.Colurellidae \\
\end{tabular}} \\
\hline Colurella obtusa (Gosse, 1886) & 67 & 22 \\
\hline \multicolumn{3}{|l|}{ Cем.Collothecidae } \\
\hline Collotheca mutabilis (Hudson, 1885) & 13 & 0 \\
\hline \multicolumn{3}{|l|}{ Cem.Conochilidae } \\
\hline Conochilus unicornis Rousselet, 1892 & 33 & 0 \\
\hline \multicolumn{3}{|l|}{ Ceм.Dicranophoridae } \\
\hline Dicranophorus lutkeni (Bergendal, 1892) & 7 & 0 \\
\hline \multicolumn{3}{|l|}{ Cем.Euchlanidae } \\
\hline Euchlanis alata Voronkov 1911 & 13 & 0 \\
\hline Euchlanis dilatata Ehrenberg, 1832 & 87 & 44 \\
\hline E. incisa Carlin, 1939 & 13 & 7 \\
\hline E. lyra Hudson, 1886 & 7 & 0 \\
\hline E. meneta Myers, 1930 & 20 & 11 \\
\hline \multicolumn{3}{|l|}{ Cем.Filinidae } \\
\hline Filinia cornuta (Weisse, 1847) & 7 & 0 \\
\hline F. longiseta (Ehrenberg, 1834) & 47 & 52 \\
\hline \multicolumn{3}{|l|}{\begin{tabular}{r|} 
Cem.Hexarthridae \\
\end{tabular}} \\
\hline Hexarthra mira (Hudson, 1871) & 47 & 33 \\
\hline \multicolumn{3}{|l|}{\begin{tabular}{|c|} 
Cem.Lecanidae \\
\end{tabular}} \\
\hline Lecane cornuta (Muller, 1786) & 47 & 7 \\
\hline L. luna (Muller, 1776) & 47 & 11 \\
\hline L. lunaris (Ehrenberg, 1832) & 7 & 37 \\
\hline L. nana (Murr, 1913) & 47 & 11 \\
\hline \multicolumn{3}{|l|}{ Ceм.Mytilinidae } \\
\hline Mytilina ventralis Ehrenberg, 1832 & 13 & 0 \\
\hline
\end{tabular}

\begin{tabular}{|c|c|c|}
\hline \multirow[t]{2}{*}{ Название таксона } & \multicolumn{2}{|c|}{$\begin{array}{l}\text { Частота встре- } \\
\text { чаемости (\%) }\end{array}$} \\
\hline & 2010 & 2013 \\
\hline \multicolumn{3}{|l|}{ Cem.Notommatidae } \\
\hline Cephalodella catellina (Muller, 1786) & 7 & 0 \\
\hline C. gibba (Ehrenberg, 1834) & 27 & 19 \\
\hline Eosphora najas (Ehrenberg, 1830) & 13 & 0 \\
\hline \multicolumn{3}{|l|}{ Cem.Phylodinidae } \\
\hline Dissotrocha aculeata (Ehrenberg, 1832) & 7 & 0 \\
\hline Habrotrocha collaris (Ehrenberg, 1832) & 33 & 11 \\
\hline Philodina roseola (Ehrenberg, 1832) & 7 & 0 \\
\hline Rotaria neptunua (Ehrenberg, 1832) & 20 & 0 \\
\hline R. rotatoria Scopoli, 1777 & & 4 \\
\hline R. tardigrada (Ehrenberg, 1832) & 33 & 0 \\
\hline \multicolumn{3}{|l|}{ Cem.Proalidae } \\
\hline Proales decipiens (Ehrenberg, 1832) & 7 & 0 \\
\hline \multicolumn{3}{|l|}{ Cem.Synchaetidae } \\
\hline Polyarthra dolichoptera Idelson, 1925 & 27 & 48 \\
\hline Polyarthra euryptera Weirzejski, 1891 & 7 & 22 \\
\hline P. major Burckhardt, 1900 & 60 & 0 \\
\hline Synchaeta oblongata Ehrenberg, 1831 & 13 & 0 \\
\hline S. pectinata Ehrenberg, 1832 & 60 & 11 \\
\hline S. tremula (Muller, 1786) & 13 & 0 \\
\hline \multicolumn{3}{|l|}{ Сем.Testundinellidae } \\
\hline Testundinella patina Hermann, 1783 & 60 & 37 \\
\hline \multicolumn{3}{|l|}{ Сем.Trichocercidae } \\
\hline Trichocerca elongata (Gosse, 1886) & 27 & 7 \\
\hline T. intermedia (Stenroos, 1898) & 27 & 0 \\
\hline T. rattus (Muller, 1776) & 0 & 13 \\
\hline T. rousseleti (Voigt, 1902) & 33 & 0 \\
\hline T. similis (Weirzejski, 1893) & 13 & 15 \\
\hline \multicolumn{3}{|l|}{ Ceм.Trichotriidae } \\
\hline Trichotria pocillum (Muller, 1786) & 47 & 22 \\
\hline
\end{tabular}

Суммарная численность коловраток в 2010 и 2013 гг. сильно различается (рис. 1).

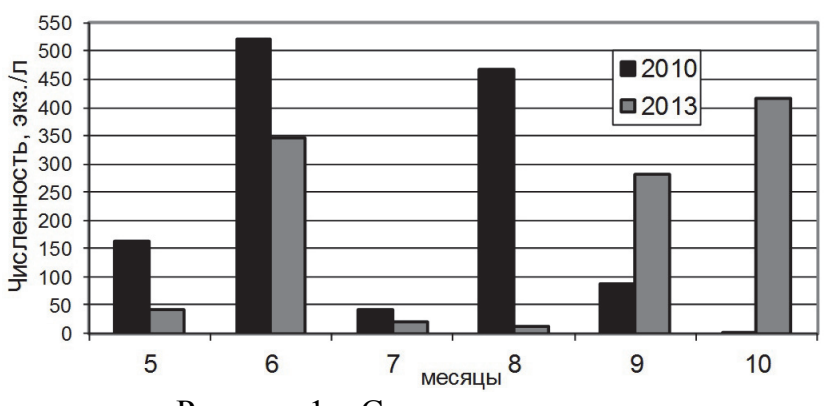

Рисунок 1 - Сезонная динамика численности коловраток

В 2013 г. рост численности коловраток происходил за счёт планктонных видов семейств Asplanchnidae, Brachionidae, и Synchaetidae (Polyarthra).

Доминирующие семейства поменялись местами: доля Synchaetidae выросла на 13\%, a Brachionidae уменьшилась на 21\%. В 27 раз выросла доля сем. Нехarthridae, в 24 раза - Testundinellidae, в 10 раз Filinidae, в 12 - Philodinidae. Уменьшился вклад только у сем. Colurellidae.

Доля планктонных видов уменьшилась в 2013 г. с 34 до 30\%, в сравнении с зарослевыми и придонными, при этом выросла численность пелагических видов. В 2013 г. доминировали виды-вертификаторы, хищные A.girodi и S.pectinata составляли $20 \%$ общей численно- 
сти. Средняя за сезон доля яйценосных особей $-20 \%$, больше всего особей с яйцами было у B.angularis и P.dolichoptera.

Ракообразных в 2013 г. выявлено в Правом пруду 20 видов из 15 родов и 7 семейств (табл. 3 ).

Таблица 3 - Виды ракообразных, обитающие в пруде у ТЦ «Пирамида» и частота (\%) их встречаемости в пробах

\begin{tabular}{|c|c|c|}
\hline \multirow[t]{2}{*}{ Название таксона } & \multicolumn{2}{|c|}{$\begin{array}{l}\text { Частота встре- } \\
\text { чаемости }(\%)\end{array}$} \\
\hline & 2010 & 2013 \\
\hline \multicolumn{3}{|l|}{ Ceм.Cyclopoidae } \\
\hline Acanthocyclops bicuspidatus Claus, 1857 & 13 & 41 \\
\hline Cyclops strenuus (Fisher, 1851) & 73 & 63 \\
\hline C. vicinus vicinus Uljanin, 1875 & 67 & 63 \\
\hline Eucyclops serrulatus (Fisher, 1851) & 73 & 7 \\
\hline Paracyclops fimbriatus (Fisher, 1853) & 7 & 0 \\
\hline T.oithonoides Sars, 1863 & 91 & 100 \\
\hline \multicolumn{3}{|l|}{ Ceм.Eudiaptomidae } \\
\hline $\begin{array}{l}\text { Eudiaptomus graciloides (Lilljeborg, } \\
\text { 1888) }\end{array}$ & 87 & 41 \\
\hline \multicolumn{3}{|l|}{ П/отр Harpacticoida } \\
\hline Harpacticoida sp. & 20 & 0 \\
\hline \multicolumn{3}{|l|}{ Ceм.Bosminidae } \\
\hline Bosmina longirostris (O.F.Muller, 1785) & 67 & 63 \\
\hline \multicolumn{3}{|l|}{ Cem.Chydoridae } \\
\hline Alona affinis (Leydig, 1860) & 0 & 30 \\
\hline A. costata Sars, 1862 & 0 & 33 \\
\hline A. quadrangularis (O.F.Muller, 1785) & 67 & 33 \\
\hline $\begin{array}{l}\text { Campocercus lilljeborgis Schoedler, } \\
1863\end{array}$ & 20 & 0 \\
\hline Chydorus globosus Baird, 1850 & 7 & 0 \\
\hline Chydorus sphaericus (O.F.Muller, 1785) & 7 & 41 \\
\hline Graptoleberis testudinaria (Fisher 1848) & 47 & 22 \\
\hline Pleuroxus aduncus (Jurine, 1820) & 20 & 19 \\
\hline P.uncinatus Baird, 1850 & 27 & 33 \\
\hline Rhynchotalona rostrata $($ Koch, 1841) & 7 & 0 \\
\hline \multicolumn{3}{|l|}{$\begin{array}{r}\text { Ceм.Daphniidae } \\
\end{array}$} \\
\hline $\begin{array}{l}\text { Ceriodaphnia quadrangula (O.F.Muller, } \\
\text { 1785) }\end{array}$ & 87 & 67 \\
\hline Daphnia longispina O.F.Muller, 1785 & 73 & 74 \\
\hline D. pulex (DeGeer, 1778) & 7 & 0 \\
\hline $\begin{array}{l}\text { Scapholeberis mucronata (O.F.Muller, } \\
\text { 1785) }\end{array}$ & 47 & 48 \\
\hline S. rammneri Dumont,Pensaert, 1983 & 13 & 0 \\
\hline Simocephalus serrulatus (Koch, 1841) & 7 & 0 \\
\hline S. vetulus (O.F.Muller, 1776) & 47 & 41 \\
\hline \multicolumn{3}{|l|}{ Ceм.Macrothricidae } \\
\hline Macrothrix sp. & 7 & 7 \\
\hline \multicolumn{3}{|l|}{ Ceм.Moinidae } \\
\hline Moina brachiata (Jurine, 1820) & 7 & 0 \\
\hline \multicolumn{3}{|l|}{ Cem.Sididae } \\
\hline $\begin{array}{l}\text { Diaphanosoma brachyurum (Lievin, } \\
\text { 1848) }\end{array}$ & 33 & 44 \\
\hline $\begin{array}{l}\text { Sida cristallina cristallina (O.F.Muller, } \\
\text { 1776) }\end{array}$ & 7 & 0 \\
\hline \multicolumn{3}{|l|}{ П/кл Ostracoda } \\
\hline Dolerocypris fasciata O.F.Muller, 1776 & 13 & 0 \\
\hline Eucypris nobilis (G.O.Sars, 1901) & 7 & 0 \\
\hline Herpetocypris reptans Baird, 1835 & 13 & 0 \\
\hline Ostracoda spp. & 80 & 30 \\
\hline
\end{tabular}

Помимо вышеперечисленных видов в 2010 г. в пробах присутствовали неидентифицированные представители подкласса Ostracoda и подотряда Harpacticoida. В 2013 г. не были найдены 13 ранее присутствующих видов и были обнаружены новых 2 вида сем. Chydoridae.

Сезонные изменения численностей ракообразных показаны на рис. 2.

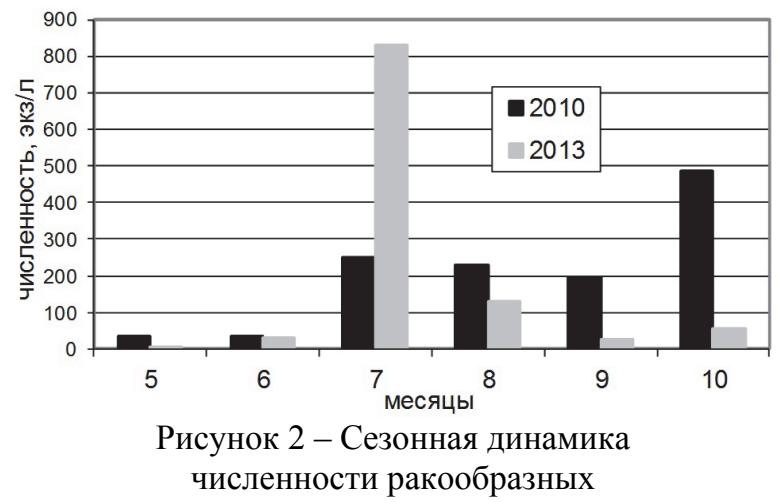

В 2013 г. численность ракообразных почти весь сезон была меньше, особенно в мае и осенью, чем в 2010 г. Рост численности в июле 2013 г. вызван активным размножением веслоногих (больше самок с яйцевыми мешками) - доля науплиев и копеподитов более $70 \%$ общей численности. В 12 раз упала численность Daphniidae, в 6 раз Eudiaptomidae, в 4 раза Sididae.

Соотношения по числу видов между планктонными, с одной стороны, придонными и зарослевыми с другой изменились слабо - в 2010 г. пелагические виды составляли $35 \%$ сообщества, в 2013 г. $-40 \%$.

Биомасса ракообразных в 2013 г. в 1,5 меньше, чем в 2010 г. и связано это с уменьшением численности популяций крупноразмерных видов.

Мы сравнили динамику суммарной численности ракообразных и коловраток за оба года исследований (рис. 3).

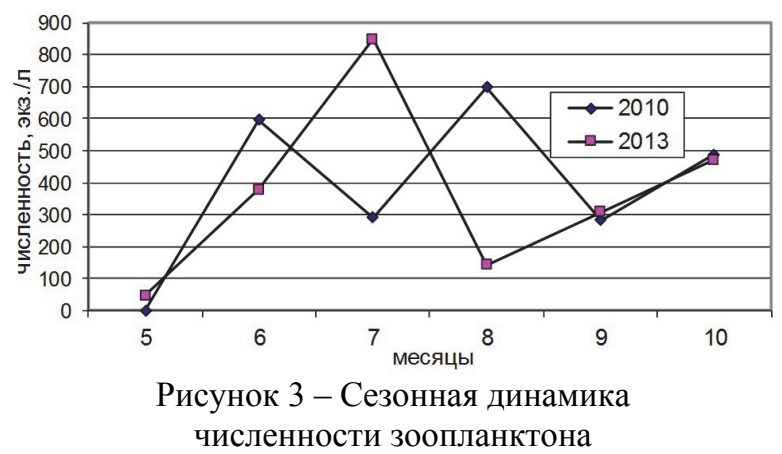

Как видно из рис. 3, в 2010 г. произошло 3 подъёма численности мезоопланктона, а в 2013 г. - только 2. В июне и августе 2010 г. подъёмы численности были обеспечены коловратками рода Keratella (около 50\% общей численности), в июле 2013 г. - науплиями циклопов. Октябрьский подъём численности в 2010 г. произошёл за счет активного размножения Daphnia longispina (77\% общей численности), в 2013 г. - коловраток рода Polyarthra (57\%) и K.cochlearis (31\%). Численность зоопланктона в 2013 г. была на 4-80\% (в среднем на $15 \%$ ) меньше, чем в 2010 г.

После реконструкции пруда значения индекса Шеннона уменьшились (коловратки с 2,92 до 2,51; ракообразные с 2,24 до 1,97). 
Обсуждение. Значительные отличия видового состава и численности коловраток и ракообразных в Правом пруду в 2013 г. по сравнению с 2010 г. связаны с сильными изменениями условий существования, вызванными как естественными причинами, так и проведённой реконструкцией. В 2013 г. было менее жарко, чаще шли дожди, поэтому уровень воды в пруду был выше, площадь акватории больше.

Работы по благоустройству вызвали серьёзные изменения в экосистеме пруда, что отразилось на видовом составе и численности коловраток и ракообразных. Наибольшее воздействие оказало удаление зарослей водо-воздушных и погружённых макрофитов. Ранее здесь обитали Ceratophyllum demersum L., Persicaria amphibia (L) S.F.Gray, Pistia stratiotus L., Salvinia natans (L) All., Alisma gramineum Lej., Phragmites australis (Cav.) Trin. ex Steud и Typha laxmanii Lepech. [7].

В 2013 г. только к концу лета появились редкие куртины рогоза, но все равно 95\% акватории было свободно от крупных растений. Этим, скорее всего, и объясняется снижение численности зарослевых видов и выпадение некоторых, а также рост численности планктонных видов. Обрамление габионами береговой линии полностью изменило характер литорали, уменьшило площадь покрытого илом мелководья. Облицовка берега, несомненно, уменьшила смыв грунта с прилегающей территории, но прозрачность воды уменьшилась только на 0,10-0,15 м. связано это, скорее всего, с увеличением количества фитопланктона, поскольку составлявшие ему ранее конкуренцию макрофиты были удалены. Полного удаления донного ила из пруда в процессе реконструкции проведено не было, поэтому число видов коловраток и ракообразных по мере восстановления зарослей будет увеличиваться. По видам-индикаторам пруд относится к $\beta$-мезосапробной зоне, уменьшилось количество видов - индикаторов загрязнения. Гидрохимические показатели пруда в целом изменились незначительно, за исключением концентрации меди. Связан ли рост содержания ионов этого металла в воде с проведёнными на пруду работами, неясно.

Заключение. Состояние данного пруда в 2013 г. можно считать удовлетворительным. С мелководий удалена большая часть мусора, благоустроена территория вокруг водоёма, некоторых местах берег огородили металлическими перилами. Визуально пруды увеличились по сравнению с предыдущими годами. Эстетическая привлекательность и рекреационная ценность во- доёма увеличились, об этом с удовлетворением говорят местные жители. Уменьшилось количество видов - индикаторов загрязнения. Это, наряду с увеличением численности планктонных видов показывает результативность проведённых мелиоративных работ.

Однако опыт очистки и восстановления непроточных водоёмов г. Казани показал, что разовыми мероприятиями ограничиваться нельзя. За прудами необходим постоянный уход: регулярное удаление накапливающихся донных осадков, периодическое укрепление берегов и мероприятия, предотвращающие смыв грунта на прилегающей территории [8].

\section{СПИСОК ЛИТЕРАТУРЫ:}

1. Герасимов Ю.Л. Городской пруд как рекреационный ресурс (на примере пруда в Кировском районе г. Самары) // Известия самарского научного центра PAH, 2010, T. 12, № 1 (4). C. 930-933.

2. Жадин В.И. Методы гидробиологического исследования. М.: Высшая школа, 1960. 189 с.

3. Каширо М.А. Влияние экологического состояния водных объектов на рекреационный потенциал городской территории (на примере г. Томска) // Вестник Томского ун-та, 2010, № 333. С. 177-180.

4. Кутикова Л.А. Коловратки фауны СССР. Л.: Наука, 1970. 744 с.

5. Кутикова Л.А. Бделлоидные коловратки фауны России. М.: ТНИ КМК, 2005. 315 с.

6. Мануйлова Е.Ф. Ветвистоусые рачки (Cladocera) фауны СССР. М.-Л.: Наука, 1964.- 326 с.

7. Матвеев В.И., Гейхман Т.В., Соловьёва В.В. Самарские пруды как объекты ботанических экскурсий. Самара: СГПУ, 1995. 44 с.

8. Набеева Н.Г. и др. Концепция восстановления озера Средний Кабан г. Казани (РФ) // Озёрные экосистемы: биологические процессы, антропогенная трансформация, качество воды. Минск: БГУ, 2011. С. 179180.

9. Определитель пресноводных беспозвоночных России и сопредельных территорий. Т. 1. Низшие беспозвоночные. СПб.: ЗИН, 1994. 394 с.

10. Определитель пресноводных беспозвоночных России и сопредельных территорий. Т.2. Ракобразные. СПб.: ЗИН, 1995. 627 с.

11. Руководство по гидробиологическому мониторингу пресноводных экосистем. СПб.: Гидрометеоиздат, 1992. $246 \mathrm{c.}$

\section{THE CRUSTCEA AND ROTIFERA IN THE POND NEAR «PIRAMIDA» SHOPPING MALL (SAMARA) IN 2013}

\section{(C) 2016}

Yu.L. Gerasimov, candidate of biological sciences, head of the Chair of Zoology, Genetics and Common Ecology Samara State Aerospace University, Samara (Russia)

A.V. Shabanova, candidate of chemical sciences, associate professor of the Chair of Hydrotechnical and Environmental Engineering Samara State University of Architecture and Civil Engineering, Samara (Russia)

Abstract. The composition and population sizez of the Crustacea and Rorifera species were studied in an urban pond after its melioration. 30 Rotifera species ( 52 species before melioration) and 20 Crustacea species ( 33 species before melioration) were found in 2013. Brachionidae, Synchaetidae и Asplanchnidae remain dominant in the Rotifera community. Cyclopoidae were dominant in the Crustacea community (Daphniidae dominated before melioration). The quantity of Bosminidae и Chydoridae considerably increased. On the whole the quantity of animal plankton decreased by $15 \%$ in 2013. In 2010 rises of the quantity were observed twice, in June and in August; in 2013 there was only one rise of the quantity of the plankton in July. The number of female individuals with eggs increased. The pond refers to the $\beta$ - 
mesosaprobic zone, the level of contamination in terms of saprobity indicators decreased. The Shannon index of species diversity was calculated. Removal of macrophytes caused decrease of littoral species and growth of plankton invertebrates. The hydrochemical analysis revealed the excess of the maximum permissible concentration of $\mathrm{BOC}_{5}, \mathrm{ASAS}_{\mathrm{S}} \mathrm{Cu}$, $\mathrm{Fe}$ and $\mathrm{Zn}$.

Keywords: urban pond, invertebrates, species composition, population size, Rotatoria, Crustacea, hydrochemical composition, Samara, reclamation, zooplankton, hydrochemical analysis, Brachionidae, Synchaetidae, Asplanchnidae, Cyclopoidae.

УДК 574.24

\section{ВЛИЯНИЕ МЕТЕОУСЛОВИЙ КАК ЭКОЛОГИЧЕСКОГО ФАКТОРА НА ВЕГЕТО-СОМАТИЧЕСКИЕ ПОКАЗАТЕЛИ ОРГАНИЗМА ДОШКОЛЬНИКОВ}

(C) 2016

А.Ю. Гордиевский, кандидат биологических наук, доцент кафедры биологии, экологии и методики обучения

Н.А. Гордиевская, кандидат биологических наук, доцент кафедры биологии, экологии и методики обучения Самарский государственный сочиально-педагогический университет, Самара (Россия)

Аннотащия. Влияние метеоэкологических факторов на людей, чувствительных к выраженным изменениям погодных условий проявляется в ухудшении самочувствия и нарушении вегетативных функций. Одной из основных систем организма, которая чутко реагирует на перепады атмосферного давления, является сердечно-сосудистая система. У людей с нарушением превентивной регуляции сосудистого тонуса, которых принято называть метеозависимыми, при резких перепадах атмосферного давления могут возникать скачки артериального давления, выражающиеся как в его повышении (гипертонический криз), так и в снижении ниже физиологической нормы, что приводит к снижению мышечного тонуса и субъективному ощущению усталости. Психофизиологическое состояние детей дошкольного возраста существенно зависит от метеорологических условий из-за несовершенства превентивной регуляции кровообращения. В связи с этим у дошкольников наблюдается ухудшение самочувствия, снижение адаптационных возможностей организма. Это проявляется в небольших скачках артериального давления и в некотором снижении лабильности двигательного анализатора, определяемым с помощью теппинг-теста. Циклонические изменения климатических условий оказывают более выраженное влияние на состояние организма, вызывая повышенное утомление и уменьшение адаптационных резервов, что свидетельствует о снижении одного из важнейших интегральных показателей - вегетативного коэффициента. Гипербарические влияния, связанные с прохождением антициклона, вызывали менее заметные изменения состояния сердечно-сосудистой системы по сравнению с циклоническими явлениями. Циклонические явления, сопровождающиеся пониженным атмосферным давлением, вызывали депрессию вегетативного статуса детей, небольшое снижение тонической активности и как следствие негативные изменения в деятельности базовых гемодинамических показателей.

Ключевые слова: метеоэкологические факторы, циклон, антициклон, метеорологические условия, артериальное давление, сердечно-сосудистая система, вегетативный коэффициент, регуляция вегетативных функций, опорно-двигательная система, гипербарические влияния, адаптационные возможности, стрессорные воздействия.

В настоящее время, когда техногенные и социальные условия активно потенциируют негативное действие экологических факторов, особенности климатических влияний становятся одним из определяющих факторов самочувствия человека $[1 ; 2 ; 3]$.

По данным медицинской статистики около 75\% людей «чувствуют погоду», кроме того, сегодня хорошо известно влияние погоды на, так называемых, метеозависимых людей, проявляющееся в ухудшении самочувствия, в обострении хронических заболеваний и даже в увеличении смертности населения. По современным представлениям метеопатические реакции (МПР) - это патологические реакции, возникающие у здоровых и больных различными нейро-соматическими заболеваниями людей в связи со сменой погоды. [4; 5; 6]. Так резкие перепады атмосферного давления могут спровоцировать ухудшение самочувствия у людей с неустойчивым собственным артериальным давлением, вегето-сосудистой дистонией, гипертонией, атеросклерозом сосудов головного мозга. Это связано с изменениями функционального состояния организма, вызванными адаптационными нагрузками пропорциональными разности (контрасту) между новыми величинами параметров и их «привычными значениями» [7; 8]. Работами многих авторов доказано, что во время измене- ния метеорологических условий особенности функциональной перестройки зависят не только от пола, длительности проживания в определенной среде, биоритмологических особенностей, но и от возраста индивида.

Медики отмечают, что в момент изменения метеорологических условий следует уделить повышенное внимание здоровью детей, так как организм ребёнка ещё не способен эффективно поддержать гомеостаз, обеспечивая физиологическую адаптацию к смене средовых условий $[9 ; 10]$.

В связи с этим, целью нашего исследования явилось изучение различных метеоусловий на вегетосоматические состояние организма детей дошкольного возраста.

Эксперимент проведен на базе ДОУ г. Самары и проходил в два этапа в течение февраля 2014 года. Первый этап во время прохождения антициклона (температура воздуха -26 градусов, атмосферное давление 784 мм. рт. ст., штиль, ясно) и второй - во время прохождения циклонического фронта (температура воздуха - 4 градуса, атмосферное давление 745 мм. рт. ст., ветер южный, 3,7 м/с, облачность, снег). В исследовании приняло участие 26 детей 6-7-летнего возраста, из них 14 девочек и 12 мальчиков. 